\title{
PEMANFAATAN SAMPAH BOTOL PLASTIK di SDN BATOK 3, TENJO, Kab. BOGOR
}

\author{
Karnelasatri \\ Jurusan Pendidikan Kimia, Fakultas Pendidikan, Universitas Pelita Harapan \\ email: nela.karnelasatri@gmail.com
}

\begin{abstract}
Abstrak
Produksi sampah plastik terus meningkat setiap tahunnya seiring dengan peningkatan jumlah penduduk di Indonesia. Sampah plastik merupakan salah satu masalah lingkungan yang besar dekade ini. Pemerintah Indonesia sendiri telah melakukan berbagai upaya untuk mengatasi permasalahan sampah secara umum sejalan dengan target Sustainable Development Goals (SDGs). Pengelolaan sampah plastik di Indonesia harus dilakukan secara menyeluruh untuk mendapatkan hasil yang optimal. Untuk itu, seluruh elemen masyarakat perlu memberikan peran aktif dalam penanganan masalah di atas. Hal ini dapat dimulai dengan edukasi tentang masalah sampah dan lingkungan pada tingkat sekolah dasar. Edukasi tentang pengelolaan sampah plastik telah dilakukan di SDN Batok 3, Tenjo, Kabupaten Bogor. Edukasi dilakukan dengan penyampaian dampak samapah plastik bagi lingkungan, pengenalan sistem hidroponik sederhana yang memanfaatkan sampah botol plastik dari sekitar sekolah serta lomba kreatifitas pembuatan celengan dan mainan sederhana. Kegiatan tersebut diharapkan mampu menumbuhkan kesadaran siswa tentang dampak sampah plastik pada lingkungan serta menambah pengetahuan siswa tentang cara-cara sederhana mendaur ulang sampah botol plastik untuk mengurangi jumlah produksi sampah plastik yang harus dibuang ke TPA maupun berakhir di ekosistem.
\end{abstract}

Kata Kunci : sampah botol plastik, hidroponik, daur ulang

\section{PENDAHULUAN}

Sampah dan limbah merupakan permasalahan nasional di Indonesia. Permasalahan tersebut disebabkan oleh lajunya pertumbuhan penduduk dimana pada 2017 jumlahnya telah mencapai 261,89 juta jiwa. Selain itu, peningkatan pertumbuhan ekonomi dan pendapatan rumah tangga telah menyebabkan semakin beragamnya pola dan jenis konsumsi masyarakat yang berakibat pada bertambahnya volume, jenis dan karakteristik sampah dan limbah yang di hasilkan. Dalam Undang-undang RI Nomor 18 Tahun 2008 dijelaskan pula bahwa selain ketiga permasalahan di atas, pengelolaan sampah yang belum sesuai dengan metode dan teknik pengelolaan sampah yang berwawaskan lingkungan juga telah menjadi salah satu alasan yang memperparah permasalahan sampah di Indonesia. Berdasarkan data KLHK, jumlah produksi sampah di Indonesia telah mencapai 65,2 juta ton per tahun. Hal tersebut berimbas pada bertambahnya berbagai masalah lingkungan dan kesehatan seperti peningkatan gas rumah kaca, banjir, penurunan kualitas air, kejadian luar biasa (KLB) diare pada 2016, dan lain sebagainya (Badan Pusat Statistik, 2018).

Kegiatan pengurangan sampah hanya berkisar 5\% dan sisanya dibuang di TPA (Tempat Pemroresan Akhir). Komposisi terbesar sampah yang ada di TPA adalah sampah organik yaitu sebesar $70 \%$, sedangkan $14 \%$ nya merupakan sampah plastik. Jumlah produksi sampah plastik diperkirakan mencapai 9,52 juta ton pada tahun 2019 (Purwaningrum, 2016). Jumlah sampah plastik di Indonesia terus meningkat seiring dengan peningkatan jumlah sampah dan limbah yang dihasilkan setiap tahunnya. Berdasarkan laporan

$$
\text { Lingkungan } 706
$$


World Economic Forum (WEF), hanya 5\% dari sampah plastik yang didaur ulang dengan efektif, sementara $40 \%$ nya berakhir di Tempat Pembuangan Akhir (TPA) sampah dan sisanya berakhir di ekosistem seperti lautan (Suara Pembaruan, 2018). Hal ini memberikan dampak buruk diantaranya penurunan kesuburan tanah, penurunan kualitas dan kuantitas air tanah, pencemaran air laut yang berimbas pada sektor wisata, kerusakan ekosistem laut dan pesisir, kematian biodiversitas, pendangkalan sungai serta penyumbatan aliran sungai yang mengakibatkan banjir (Arifin, 2017). Selain itu, berbagai jenis zat aditif pada sampah plastik berpotensi menjadi penyebab kanker dan ganguan edokrin. Penanggulangan sampah plastik dengan cara dibakar akan menyebabkan polusi udara dan menghasilkan logam berat, dioksin, dan PCB yang menggagu sistem pernafasan serta menyebabkan lebih dari 6 juta kasus kematian. Dekomposisi sampah plastik di TPA pun menghasilkan gas rumah kaca seperti $\mathrm{CO}_{2}$ dan $\mathrm{CH}_{4}$ yang memperparah pemanasan global. (Alabi, Ologbonjaye, Awosolu, \& Alalade, 2019). Di Indonesia sendiri potensi gas metana $\left(\mathrm{CH}_{4}\right)$ yang dihasilkan dari sektor sampah perkotaan sangat besar dimana jumlahnya mencapai 109,96 Gg per tahun (Purwanta, 2009). Dampak-dampak negatif diatas diperparah dengan keberadaan mikroplastik yang dihasilkan dari dekomposisi sampah plastik di perairan yang dapat terakumulasi dan mencemari ekosistem serta rantai makanan (Directorate General for Environment of European Commission, 2011). Pencemaran akibat mikroplastik di perairan bahkan berdampak negatif bagi kesejahteraan manusia secara ekonomi maupun secara sosial khususnya pada area perikanan, warisan keberagaman sumber daya laut dan sekitarnya serta area pariwisata (Beaumont, et al., 2019). Selain itu, pencemaran mikroplastik di daratan juga dapat mengubah karakteristik tanah dan mempengaruhi sifat tanaman (Machado, et al., 2019).

Melihat besarnya dampak dari pencemaran sampah plastik akibat pengelolaan yang kurang baik, maka diperlukan peran aktif seluruh kalangan tidak terkecuali masyarakat Indonesia. Pemerintah Indonesia telah melakukan berbagai upaya dalam mengatasi masalah sampah dan limbah secara umum seperti yang tertuang dalam Perpres 97
Tahun 2017 yang sejalan dengan target Sustainable Development Goals (SDGs) dimana penanganan sampah yang ditargetkan adalah sebesar 70\% (Badan Pusat Statistik, 2018). Dalam menangani sampah plastik pemerintah telah membuat gerakan bank sampah, program kampung hijau, peningkatan prasarana untuk penanganan dan pengelolaan sampah di aliran air, bantuan dan kerjasama dengan berbagai pabrik daur ulang dan lain sebagainya (World Bank Group, 2018).

Seluruh upaya yang dilakukan oleh pemerintah di atas tidak akan berjalan maksimal jika tidak dibarengi oleh kesadaran dan dukungan dari masyarakat. Masyarakat perlu memiliki kesadaran tentang dampak sampah plastik, mengurangi konsumsinya serta mengelolanya dengan tepat. Kesadaran tersebut diharapkan dapat meningkatkan gerakan daur ulang sampah dan mengurangi jumlah sampah yang harus dibuang ke TPA ataupun berakhir di ekosistem. Hal ini dapat meminimalisasi dampak negatif, kerugian serta potensi konflik sosial yang ditimbulkan terhadap penetapan lokasi dan pengelolaan TPA (Mahyudin, 2017).

Kesadaran masyarakat untuk berkontribusi langsung dalam permasalahan sampah dapat dibangun dengan berbagai bentuk pendekatan. Salah satu bentuk pendekatan yang dilakukan adalah penanganan sampah berbasis sosial budaya. Studi dengan basis ini pernah dilakukan di Bali dimana upaya strategis yang dikembangkan untuk mengatasi permasalah sampah dilakukan secara adaftif dengan memperhatikan berbagai aspek seperti karakteristik sosial dan budaya masyarakat, ruang (lingkungan), serta volume dan jenis sampah yang dihasilkan. Dengan memperhatikan aspekaspek tersebut, bentuk upaya yang disarankan antara lain peningkatan peran lembaga tradisional (desa tradisional/banjar), LSM Lingkungan dan pemerintah setempat, implementasi aturan adat, promosi bentuk umum pengelolaan sampah 3R (mengurangi, menggunakan kembali dan mendaur ulang) serta menggagas kembali tradisi gotong royong (Wardi, 2011). Contoh lain dari penanganan sampah yang dilakukan dengan pendekatan sosial juga pernah dilakukan di daerah aliran sungai Karangmumus yang melewai tiga kecamatan Samarinda yaitu Samarinda Utara, Samarinda Ulu dan Samarinda Ilir. Dalam studi yang dilakukan

$$
\text { Lingkungan }
$$


dengan metode penyebaran kuisioner diperoleh nilai $67,7 \%$ sikap negatif yang ditunjukan oleh responden dalam pengelolaan sampah. Berdasarkan hasil analisa pada permasalahan yang dihadapi maka penanganan sampah yang disarankan lebih dalam bentuk upaya membangun kesadaran masyarakat dalam bentuk pendidikan dan pelatihan, peningkatan prasarana, komunisasi dengan pihak terkait serta penggalakan aturan hukum (Sudiran, 2005).

Pendekatan lain yang dapat dilakukan untuk mengelola sampah adalah pendekatan yang berbasis masyarakat. Pengelolaan sampah terpadu berbasis masyarakat merupakan suatu pendekatan pengelolaan sampah yang didasarkan pada kebutuhan dan permintaan masyarakat serta direncanakan, dilaksanakan, dikontrol dan di evaluasi bersama oleh masyarakat dimana pemerintah dan lembaga lainnya berperan sebagai motivator dan fasilitator. Fungsi motivator dan fasilator adalah memberi dorongan dan bantuan pada masyarakat agar secara mandiri dapat memikirkan, mencari solusi serta melaksanakan kegiatan untuk menangani permasalahan sampah yang mereka hadapi. Pendekatan dengan basis ini tentu memerlukan kesiapan masyarakat yang matang (Subekti, 2010). Untuk menyiapkan masyarakat yang dapat mengelola sampah secara mandiri maka pendekatan pengelolaan sampah lain yang dapat dilakukan haruslah berbasis pendidikan. Bentuk kegiatan yang dilakukan dapat berupa penyuluhan, pembinaan dan pelatihan seperti pemanfaatan limbah plastik dan kain perca menjadi kerajinan tangan dan memiliki nilai jual di Sumberejo Pakal, Surabaya (Anindita, Setiawan, Purwidi, \& Sari, 2017) serta penyuluhan 4R (Reduce, Reuse, Recycle, Replace) dan kegunaan bank sampah di Desa Mojowuku Kabupaten Gresik (Kusminah, 2018).

Berdasarkan beberapa hasil studi maupun kegiatan yang telah dijabarkan di atas, dapat diamati bahwa edukasi untuk membangun kesadaran dan kesiapan masyarakat untuk dapat secara mandiri berpatisipasi aktif dalam menyelesaikan masalah sampah sangat diperlukan. Konsep mengenai dampak negatif sampah dan bentuk umum pengelolaan sampah 3R (Reduce, Reuse dan Recycle) masih sangat rendah dan tidak merata diketahui oleh masyarakat. Untuk itu berbagai bentuk edukasi berupa penyuluhan, pendidikan, pelatihan maupun workshop perlu dilakukan oleh pemerintah maupun berbagai lembaga tidak terkecuali lembaga pendidikan tinggi. Lembaga dapat melaksanakan peran aktif untuk mempersiapkan masyarakat mandiri yang perduli sampah. Peran aktif lembaga dapat di awali dengan memberikan edukasi untuk menumbuhkan kesadaran tentang masalah sampah dan lingkungan ditingkat sekolah dasar. Edukasi tentang pengelolaan sampah plastik telah dilakukan di SDN Batok 3, Tenjo, Kab. Bogor. Bentuk kegiatan yang dilakukan adalah penjelasan mengenai dampak plastik bagi lingkungan yang dilanjutkan dengan pengenalan sistem hidroponik sederhana yang memanfaatkan sampah botol plastik di sekitar sekolah serta lomba kreatifitas pembuatan mainan sederhana. Serangkaian kegiatan tersebut diharapkan menumbuhkan kesadaran siswa dan warga sekolah tentang dampak sampah plastik pada lingkungan dan kesehatan manusia serta menambah pengetahuan siswa tentang cara-cara sederhana mendaur ulang sampah botol plastik untuk mengurangi jumlah produksi sampah plastik tersebut.

\section{METODE}

Pelaksanaan kegiatan terbagi dalam dua tahap. Tahap pertama adalah survei lapangan dan sosialisasi kegiatan. Survei lapangan bertujuan untuk menganalisa situasi dan kondisi Mitra dalam hal ini SDN Batok 3, Tenjo, Kab. Bogor sedangkan sosialisasi kegiatan bertujuan untuk menentukan sasaran kegiatan dan partisipasi yang dapat dilakukan oleh pihak sekolah, pemerintah setempat dan masyarakat sekitar. Berdasarkan tahap pertama tersebut ditentukanlah bahwa sasaran dari kegiatan ini adalah siswa kelas 4, 5 dan 6. Tahap kedua adalah pelaksanaan kegiatan yang melibatkan mahasiswa sebagai fasilitator dan dosen sebagai narasumber. Bentuk kegiatan yang dilakukan adalah penyampaian dampak sampah plastik terhadap lingkungan dan kesehatan manusia kepada siswa kelas 4, 5 dan 6 dengan ceramah, diskusi kelompok dan presentasi. Kegiatan kemudian dilanjutkan dengan pemanfaatan sampah botol plastik sebagai

$$
\text { Lingkungan } \quad 708
$$


bahan dasar pembuatan media tanam hidroponik sederhana bagi siswa kelas 6 serta lomba kreatifitas pembuatan mainan sederhana bagi siswa kelas 4 dan 5. Untuk mendukung kegiatan tersebut diperlukan beberapa alat dan bahan antara lain botol plastik bekas dan sabut kelapa yang dikumpulkan siswa dari lingkungan sekitar, kain bekas, bibit tanaman, nutrisi hidroponik, kertas warna, karton, gunting, lem, pisau cutter, kain panel berbagai warna, spidol berbagai warna, benang wol berbagai warna, kardus bekas, print dari gambar-gambar dampak negatif sampah plastik, air dan ember. Semua kegiatan didukung oleh warga sekolah seperti kepala sekolah, guru, staf sekolah serta tim Sevice Learning Universitas Pelita Harapan.

\section{HASIL DAN PEMBAHASAN}

\section{Survei Lapangan dan Sosialisasi Kegiatan}

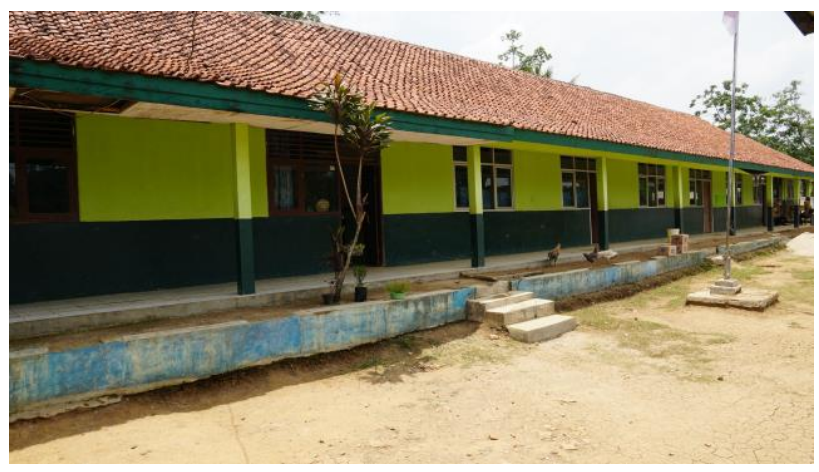

(a)

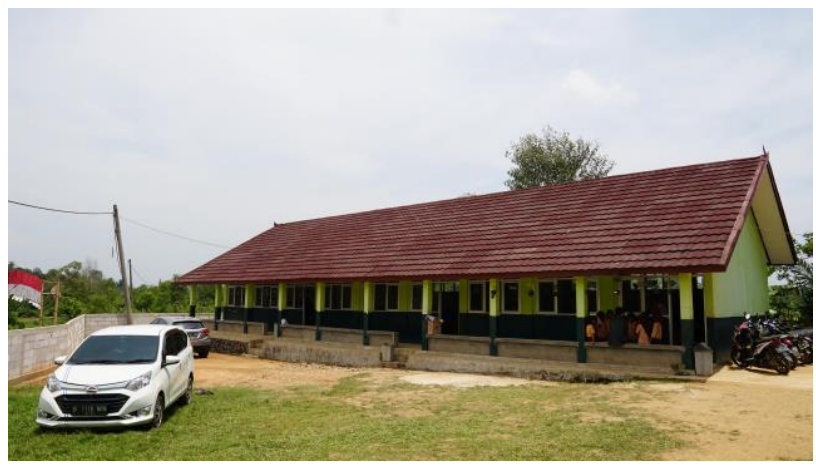

(b)

Gambar 1. (a) Gedung kelas 1-3 dan ruang guru, (b) Gedung kelas 4-6 SDN Batok 3
SDN Batok 3 terletak di desa Batok, kecamatan Tenjo, kabupaten Bogor. Sekolah ini terdiri dari dua gedung, 2 kamar kecil, lapangan yang cukup luas dan pagar sekolah. Gedung pertama adalah kelas 1, 2, 3 dan kantor guru sedangkan gedung kedua adalah kelas 4, 5 dan 6 . Keadaan sekolah baik dan bersih, namun hanya ada 1 bak sampah besar. Fasilitas jalan menuju sekolah ini kurang baik kondisinya, jalan masih berbatu, berlubang dan ruas jalan juga tidak begitu besar hanya berkisar $2 \mathrm{~m}$ serta masih banyak terlihat sampah plastik yang dibuang di samping jalan dan lingkungan tempat tinggal menuju sekolah ini. Hal ini menjadi salah satu penanda bahwa kesadaran warga sekitar tentang dampak dan pengelolaan sampah plastik masih perlu ditingkatkan. Jumlah siswa disekolah ini sekitar 250 siswa dengan 40-45 siswa per kelas. Ruangan kelas kondisinya baik namun tidak dilengkapi dengan komputer dan proyektor. Fasilitas pembelajaran yang ada adalah papan tulis, buku-buku, alat-alat peraga serta posterposter hasil karya siswa. Setelah menyampaikan bentuk kegiatan yang akan dilakukan, pihak sekolah dan pelaksana kegiatan menyepakati bahwa sasaran kegiatan yang sesuai dengan bentuk kegiatan dan peralatan yang digunakan serta kemampuan siswa dan tingkat materi pelajaran yang sedang dan telah mereka pelajari di sekolah adalah siswa-siswi kelas 4, 5 dan 6. Melalui kegiatan ini, selain untuk mencapai tujuan awal yaitu terbentuknya kesadaran siswa-siswi tentang daur ulang sampah sejak dini, pihak sekolah juga mengharapkan siswa-siswi mendapat model pembelajaran tambahan yang dapat memperkaya para siswa dalam memahami materi pelajaran disekolah khususnya untuk pelajaran ilmu pengetahuan alam (IPA).

\section{Pelaksanaan Kegiatan}

Kegiatan pengabdian pada masyarakat di SDN Batok 3 di awali dengan penyampaian materi tentang dampak sampah plastik bagi lingkungan oleh dosen. Penyampaian materi dilakukan pada kelas 4, 5 dan 6 lewat ceramah yang dilanjutkan dengan diskusi dan presentasi kelompok. Metode ini dipilih karena sekolah tidak memiliki fasilitas pembelajaran seperti proyektor dan komputer untuk menyampaikan materi pelajaran. Oleh karena itu, media yang digunakan adalah gambar-gambar dampak sampah plastik bagi lingkungan dan 
kesehatan manusia yang diambil dari berbagai sumber dari internet dan print di kertas foto dengan ukuran A4 dengan mencantumkan sumber gambar tersebut. Hasil print dari gambar-gambar tersebut kemudian dipotong menjadi beberapa bagian oleh satu kelompok. Potongan-potongan tersebut kemudian dianggap sebagai puzzle dan ditukar dengan kelompok lain. Siswa-siswi menyusun puzzle yang didapat kemudian menempelkannya pada sebuah karton. Kegiatan ini dibantu oleh fasilitator yang dalam hal ini adalah mahasiswa. Selain itu, dosen dan fasilitator menjelaskan makna dari gambar-gambar tersebut. Siswa-siswi per kelompok kemudian diberi kesempatan mempresentasikan pengetahuan yang didapat beserta menunjukkan gambar yang berhasil disusun. Keseluruhan tahap ini kemudian disimpulkan oleh dosen.

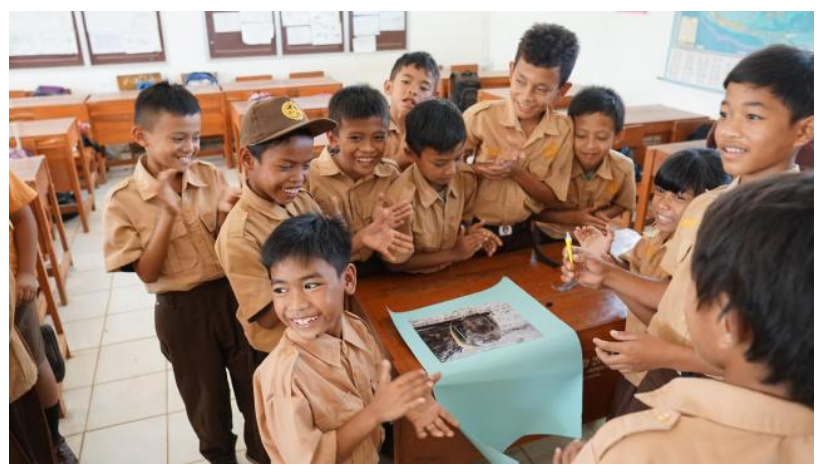

Gambar 2. Diskusi dan presentasi kelompok

Kegiatan kemudian dilanjutkan dengan pembuatan media tanam hidroponik sederhana dengan memanfaatkan sampah botol plastik dan sabut kelapa dari lingkungan sekitar. Kegiatan ini diberikan kepada siswa kelas 6 dan dibantu oleh fasilitator. Media tanam dibuat dengan langkahlangkah sederhana berikut: 1) Botol plastik bekas dibagi menjadi dua bagian dengan cara dipotong bagian tengahnya; 2) Bagian bawah botol kemudian menjadi wadah campuran air dan nutrisi hidroponik; 3) Bagian tutup ditambahkan kain bekas dengan melubangi bagian tutupnya dan kemudian ditambahkan serabut kelapa sebagai media tanam. Serabut kelapa yang digunakan telah direndam terlebih dahulu sehingga teksturnya lembab dan tidak terlalu keras; 4) Bagian tutup kemudian dibalik dan dipasangkan pada bagian bawah botol hingga kain yang telah ditambahkan terendam sebagian oleh campuran air dan nutrisi hidroponik; 5) Pada media tanam tersebut kemudian di tambahkan bibit tanaman kankung dan dipasang tali agar bisa digantung dibeberapa tempat dan lokasi disekolah tersebut. Cara membuat media tanam hidroponik diperagakan oleh dosen terlebih dahulu kemudian di ikuti oleh setiap siswa kelas 6. Setiap siswa membuat 1-2 media tanam hidroponik dan meletakannya di kelas atau menggantungnya dibeberapa area sekolah. Sebagian siswa bahkan membawa pulang media tanam yang berhasil mereka buat. Media tanam ini tidak hanya dapat dipakai untuk menanam sayuran hidroponik, siswa juga menggunakan media tanam tersebut untuk menanam biji kacang dan mengamati pertumbuhan kecambahnya. Hal ini membantu mereka dalam memahami mata pelajaran IPA. Dalam perkembanagannya, saat siswa menumbuhkan kecambah dengan media tanam hidroponik, mereka dapat mengamati pertumbuhan akar dengan jelas karena kecambah dapat di angkat perlahan tanpa merusak bagian akarnya. Selain itu, siswa juga dapat membandingkan pertumbuhan kecambah pada media tanam hidroponik dengan media tanam tanah biasa. Berdasarkan perbandingan tersebut, guru dapat menjelaskan penyerapan nutrisi yang dilakukan oleh akar. Dengan demikian media tanam ini dapat menambah model pembelajaran yang dapat membantu guru dalam menjelaskan dan memvisualisasikan secara langsung materi pelajaran IPA di kelas. Selain itu, kegiatan ini juga menambah wawasan siswa tentang jenis-jenis media tanam.

Selain pembuatan media tanam hidroponik sederhana kegiatan lain yang dilakukan adalah lomba kreatifitas pembuatan mainan sederhana berbahan dasar botol plastik. Kegiatan ini dibantu oleh mahasiswa dari jurusan design dan diberikan kepada siswa kelas 4 dan 5. Salah satu bentuk kreatifitas yang dibuat adalah mainan kura-kura yang juga dapat dijadikan celengan. Mainan ini dibuat dengan langkah-langkah sederhana berikut: 1) Bagian bawah botol plastik dipotong setinggi kurang lebih 3-5 $\mathrm{cm}$, bagian ini dijadikan sebagai tempurung sang kura-kura; 2) Kain panel berbagai berwarna dan kardus bekas dipotong dengan bentuk kura-kura; 3) Kain panel kemudian ditempelkan

$$
\text { Lingkungan }
$$


pada kardus bekas dengan lem; 4) Bagian bawah botol plastik pada tahap pertama kemudian ditempalkan secara proporsional pada kain panel tersebut; 5) Mainan kura-kura ini kemudian dihias dengan berbagai cara misalnya mewarnainya dengan spidol marker berwarna atau menambahkan benang wol agar bentuknya menarik; 6) Mainan kura-kura tersebut dapat juga dimanfaatkan sebagai celengan dengan melubangi seukuran uang koin bagian bawah dari tempelan kardus dan kain panel. Cara membuat mainan kura-kura diperagakan oleh fasilitator terlebih dahulu kemudian dilanjutkan dengan lomba kreatifitas. Siswa-siswi dibagi dalam beberapa kelompok dan diberikan perlengkapan untuk membuat kreasi mainan kura-kura. Pada tahap ini, sambil mengawasi dan membantu para siswa-siswi yang berkreasi, fasilitator juga menjelaskan bahwa selain mainan kura-kura masih banyak bentuk mainan maupun kreasi lain yang dapat dibuat dengan memanfaatkan botol plastik bekas. Para fasilitator juga menunjukan bentukbentuk kreasi tersebut serta langkah-langkah membuatnya pada beberapa lembar kertas yang telah mereka print terlebih dahulu. Fasilator juga menyampaikan manfaat kegiatan serta potensi kontribusi positifnya bagi lingkungan dan kesehatan masyarakat sekitar. Setelah selesai, hasil kreasi dikumpulkan dan ditentukan pemenangnya.

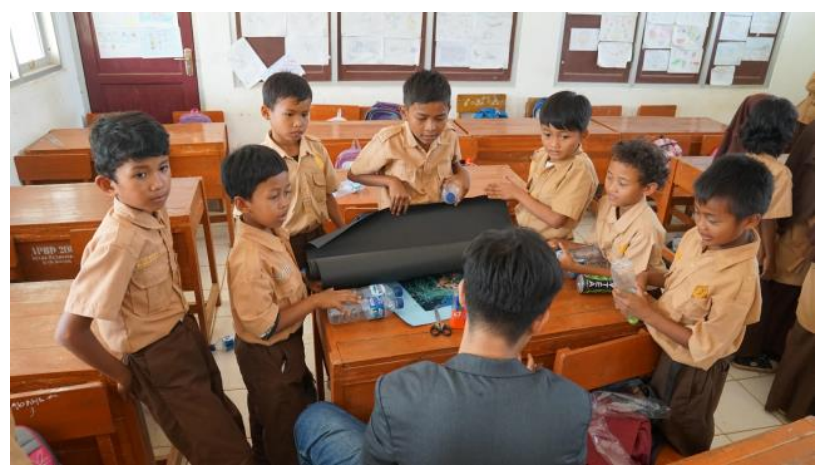

Gambar 3. Kegiatan pembuatan mainan sederhana

Pada awal dan sela-sela kegiatan secara bergantian semua siswa-siswi juga di ajak menyanyikan beberapa buah lagu bersama yang di iringi dengan gitar dan dipandu oleh fasilitator dari mahasiswa jurusan musik. Seluruh rangkaian kegiatan diatas di ikuti oleh para siswa dengan sangat antusias. Kegiatan kemudian dilanjutkan dengan pembagian hadiah berupa pensil kepada seluruh siswa-siswi yang terlibat dalam kegiatan ini dan buku tulis pada kelompok-kelompok yang memenangkan lomba kreatifitas. Kegiatan kemudian di akhiri dengan ramah tamah bersama seluruh siswa-siswi yang terlibat, warga sekolah, pelaksana dan perwakilan pemerintah setempat yang mendukung penuh keberlangsungan kegiatan ini. Selain itu dilakukan penyerahan tanda terima kasih dari pihak sekolah dan foto bersama. Selain memberi dampak positif bagi pihak sekolah, kegiatan ini juga memberikan pengalaman yang baik bagi para mahasiswa yang terlibat sebagai fasilitator karena mereka dapat berkontribusi dan terjun secara langsung untuk membangun masyarakat.

\section{KESIMPULAN}

Pengabdian kepada masyarakat dalam bentuk kegiatan daur ulang sampah plastik telah dilakukan di SDN Batok 3, Tenjo, Kab. Bogor. Kegiatan ini diharapkan dapat menanamkan kesadaran kepada siswa-siswi sekolah tersebut tentang pentingnya pengurangan konsumsi plastik dan menambah wawasan mereka tentang pengelolaan sampah plastik dengan cara daur ulang.

\section{UCAPAN TERIMAKASIH}

Terimakasih kepada Universitas Pelita Harapan dan SDN Batok 3, Tenjo, Kab. Bogor yang telah memberikan kesempatan kepada saya untuk dapat menjadi narasumber pada kegiatan ini. Terimakasih juga saya ucapkan kepada pemerintah setempat, para mahasiswa yang menjadi fasilitator dan seluruh pihak yang mendukung pelaksanaan kegiatan ini sehingga berjalan dengan baik.

\section{REFERENSI}

Alabi, O. A., Ologbonjaye, K. I., Awosolu, O., \& Alalade, O. E. (2019). Public and Environmental Health Effects of Plastic Wastes Disposal: A Review. Journal of Toxicology and Risk Assessment, 5(2), 1-13.

Anindita, G., Setiawan, E., Purwidi, A., \& Sari, D. P. (2017). Pemanfaatan Limbah Plastik dan Kain Perca Menjadi Kerajinan Tangan Guna Meningkatkan Kualitas Sumber Daya Manusia. Seminar MASTER 2017 PPNS, pp. 173-176. Surabaya.

$$
\text { Lingkungan }
$$


Arifin, M. Z. (2017). Dampak Sampah Plastik Bagi Ekosistem Laut. 14, pp. 44-48.

Badan Pusat Statistik. (2018). Statistik Lingkungan Hidup Indonesia 2018. Statistik Lingkungan Hidup Indonesia, p. 250.

Beaumont, N. J., Aanesen, M., Austen, M. C., Börger, T., Clark, J. R., Cole, M., et al. (2019). Global Ecological, Social and Economic Impacts of Marine Plastic. Marine Pollution Bulletin, 142, 189-195.

Directorate General for Environment of European Commission. (2011). Plastic Waste: Ecological and Human Health Impacts.

Kusminah, I. L. (2018). Penyuluhan 4r (Reduce, Reuse, Recycle, Replace) dan Kegunaan Bank Sampah Sebagai Langkah Menciptakan Lingkungan yang Bersih dan Ekonomis di Desa Mojowuku Kabupaten Gresik. Jurnal Pengabdian Masyarakat LPPM Untag, 3(1), 22-28.

Machado, A. A., Lau, C. W., Kloas, W., Bergmann, J., Bachelier, J. B., Faltin, E., et al. (2019). Microplastics Can Change Soil Properties and Affect Plant. Environmental Science and Technology, 53, 6044-6052.

Mahyudin, R. P. (2017). Kajian Permasalahan Pengelolaan Sampah dan Dampak Lingkungan di TPA (Tempat Pemrosesan Akhir). Jukung Jurnal Tekhnik Lingkungan, 3(1), 66-74.
Purwaningrum, P. (2016). Upaya Mengurangi Timbulan Sampah Plastik di Lingkungan. Indonesian Journal of Urban and Environmental Technology, 141-147.

Purwanta, W. (2009). Perhitungan Emisi Gas Rumah Kaca (GRK) dari Sektor Sampah Perkotaan di Indonesia. Jurnal Teknologi Lingkungan-Badan Pengkajian dan Penerapan Teknologi, 10(1), 1-8.

Suara Pembaruan. (2018, April 25).

Subekti, S. (2010). Pengelolaan Sampah Rumah Tangga 3R Berbasis Masyarakat. Seminar Nasional Sains dan Teknologi 1 2010, 1, pp. 24-30. Semarang.

Sudiran, F. (2005). Instrumen Sosial Masyarakat Karangmumus Kota Samarinda dalam Penanganan Sampah Domestik. Makara, Sosial Humaniora, 6(1), 16-26.

Wardi, I. N. (2011). Pengelolaan Sampah Berbasis Sosial Budaya: Upaya Mengatasi Masalah Lingkungan di Bali. Jurnal Bumi Lestari, 11, 167-177.

World Bank Group. (2018). Hotspot Sampah Laut Indonesia. 